\title{
Identification and functional characterization of small non-coding RNAs in Xanthomonas oryzae pathovar oryzae
}

\author{
Hong Liang ${ }^{1,2,3}$, Ying-Tao Zhao ${ }^{2,3,4}$, Jie-Qiong Zhang ${ }^{1,2}$, Xiu-Jie Wang ${ }^{2,4}$, Rong-Xiang Fang ${ }^{1,2^{*}}$, Yan-Tao Jia ${ }^{1,2^{*}}$
}

\begin{abstract}
Background: Small non-coding RNAs (sRNAs) are regarded as important regulators in prokaryotes and play essential roles in diverse cellular processes. Xanthomonas oryzae pathovar oryzae (Xoo) is an important plant pathogenic bacterium which causes serious bacterial blight of rice. However, little is known about the number, genomic distribution and biological functions of sRNAs in XoO.

Results: Here, we performed a systematic screen to identify sRNAs in the XoO strain PXO99. A total of 850 putative non-coding RNA sequences originated from intergenic and gene antisense regions were identified by cloning, of which 63 were also identified as sRNA candidates by computational prediction, thus were considered as Xoo sRNA candidates. Northern blot hybridization confirmed the size and expression of 6 sRNA candidates and other 2 cloned small RNA sequences, which were then added to the sRNA candidate list. We further examined the expression profiles of the eight sRNAs in an hfa deletion mutant and found that two of them showed drastically decreased expression levels, and another exhibited an Hfq-dependent transcript processing pattern. Deletion mutants were obtained for seven of the Northern confirmed sRNAs, but none of them exhibited obvious phenotypes. Comparison of the proteomic differences between three of the $\triangle$ sRNA mutants and the wild-type strain by two-dimensional gel electrophoresis (2-DE) analysis showed that these sRNAs are involved in multiple physiological and biochemical processes.

Conclusions: We experimentally verified eight sRNAs in a genome-wide screen and uncovered three Hfqdependent sRNAs in Xoo. Proteomics analysis revealed Xoo sRNAs may take part in various metabolic processes. Taken together, this work represents the first comprehensive screen and functional analysis of sRNAs in rice pathogenic bacteria and facilitates future studies on sRNA-mediated regulatory networks in this important phytopathogen.
\end{abstract}

\section{Background}

As an emerging class of gene expression modulators, small non-coding RNAs (sRNAs) have been detected in almost all kingdoms of life and are gaining increasing attention because of their important roles in various physiological processes. With the rapid progress of research on bacterial transcriptome, hundreds of sRNAs have been identified. Subsequent functional analyses have revealed that these sRNAs regulate various cellular processes, such as stress responses [1], quorum sensing [2],

\footnotetext{
* Correspondence: fangrx@im.ac.cn; jiayt@im.ac.cn

'State Key Laboratory of Plant Genomics, Institute of Microbiology, Chinese Academy of Sciences, Beijing 100101, PR China

Full list of author information is available at the end of the article
}

life cycle differentiation [3] and virulence [4-7]. Systematic screen of sRNAs have been performed in diverse bacteria, such as Escherichia coli [8-11], Salmonella enterica [12], Pseudomonas aeruginosa [13] and many other bacterial species distantly related to E. coli [14-18]. These studies reveal that sRNAs are widely encoded in bacterial genomes, the discovery pace of bacterial sRNAs has continued to accelerate and the functions of increasing sRNAs are being elucidated [19].

Bacterial sRNAs are usually 50-500 nucleotides (nt) in length. Besides binding with proteins to modulate their activities, the majority of sRNAs regulate their target genes by base pairing and function as diffusible molecules [20]. The base pairing sRNAs can be further
C Biomed Central

(c) 2011 Liang et al; licensee BioMed Central Ltd. This is an Open Access article distributed under the terms of the Creative Commons Attribution License (http://creativecommons.org/licenses/by/2.0), which permits unrestricted use, distribution, and reproduction in any medium, provided the original work is properly cited. 
classified into two subgroups: trans-encoded sRNAs and cis-encoded sRNAs. Of them, trans-encoded sRNAs have been well-studied during the last two decades. These sRNAs are transcribed from the genomic loci which are physically unlinked to their target genes. Trans-encoded sRNAs usually regulate the translation or stability of their target mRNAs through partial and discontinuous complementarities. The trans-encoded sRNAs resemble the eukaryotic microRNAs in their ability to modulate mRNA stability and translation $[19,20]$. In addition, most of the trans-encoded sRNAs require the bacterial $\mathrm{Sm}$-like protein, $\mathrm{Hfq}$, to perform their regulatory functions [21]. Hfq plays important roles in sRNAs-mediated regulation by affecting the stability of sRNAs and facilitating the base-pairing between sRNAs and their target mRNAs [22]. The $h f q$ mutant exhibits various phenotypes in many bacterial species, including reduced growth rate, changed pathogenicity and altered tolerance to stress conditions [23-28]. Another subgroup of antisense sRNAs is the cis-encoded sRNAs which are transcribed from the opposite strand of their target genes and regulate their target genes through complete complementarities [29]. Although most of the identified cis-encoded sRNAs are encoded by phages, plasmids and transposons [30], recent studies revealed that bacterial chromosomes also generate a large number of cis-encoded sRNAs. Besides, RNA regulators such as riboswitches and CRISPR (clusters of regularly interspaced short palindromic repeats) RNAs also play regulatory roles and exist widely in bacteria [20].

Xanthomonas oryzae pathovar oryzae (Xoo) is a Gramnegative bacterium that belongs to the gamma subdivision of Proteobacteria and is the causal agent of the bacterial blight of rice. Xoo has long been used as a model organism in studying plant pathology. Currently, the complete genomic sequences of three Xoo strains are available [31-33], allowing for genome-scale analysis. During the past few years, a number of regulatory genes were identified in $\mathrm{Xoo}$, especially those involved in virulence and host cell recognition, but very little is known about sRNAs and sRNA-mediated regulations in this bacterium. Bona fide small regulatory RNAs have not yet been described in Xoo, although some house-keeping sRNAs, regulatory RNAs such as riboswitches [34] and CRISPR RNAs [35] were reported. In the Xanthomonas genus, only four sRNAs from Xanthomonas campestris pv.campestris (Xcc) [36], the causal agent of black rot disease of crucifers, and a plasmid transferred anti-sense sRNA from Xanthomonas campestris pv. vesicatoria $(X c v)$ [37] were reported previously. Therefore, the presence of sRNAs in Xoo genome and their regulatory functions remain to be elucidated.

Here, we conducted a global screen for sRNAs in the Xoo strain PXO99 by experimental cloning coupled with computational prediction. This work aimed: 1) to understand the number, genomic distribution and subgroups of Xoo sRNAs; 2) to examine the expression of some sRNAs for future studies, and 3) to screen for putative target genes of sRNAs of interest by a proteomic assay. In total, we obtained 65 putative sRNA candidates within the Xoo genome. Among them, the expression of eight sRNAs was experimentally confirmed, and three of them were determined to be Hfq-dependent sRNAs. We successfully constructed seven sRNA-deleted mutants, and proteomic analysis performed on three of these mutants indicated that the corresponding sRNAs are likely to be involved in various physiological pathways. The results of this study will facilitate future investigations on sRNAs functions in this important phytopathogenic bacterium.

\section{Results and Discussion}

\section{Identification of candidate sRNA genes in Xoo}

A cDNA library of RNAs with the size ranging from 50 to 500 nt was generated from the Xoo strain PXO99 grown under standard laboratory conditions to study its population of sRNAs. As the expression of some bacterial sRNAs has been reported to be up-regulated around the stationary phase $[8,11,38]$, we used total RNA extracted from the Xoo cells in the stationary phase $\left(\mathrm{OD}_{600}=1.5\right)$ in this study. A total of 10,560 individual clones were pre-screened by hybridization on customermade arrays to eliminate clones containing rRNA or tRNA sequences. Subsequently, 3,443 cDNA clones exhibiting low hybridization signals were sequenced. The obtained sequences were analyzed and classified according to their annotation and genomic locations (Additional file 1 and Figure 1). A total of 190 lowquality sequences were excluded from further studies either due to their short sequence lengths or lack of complete adapter sequences. There were still 278 and 81 cDNA clones corresponding to the fragments of

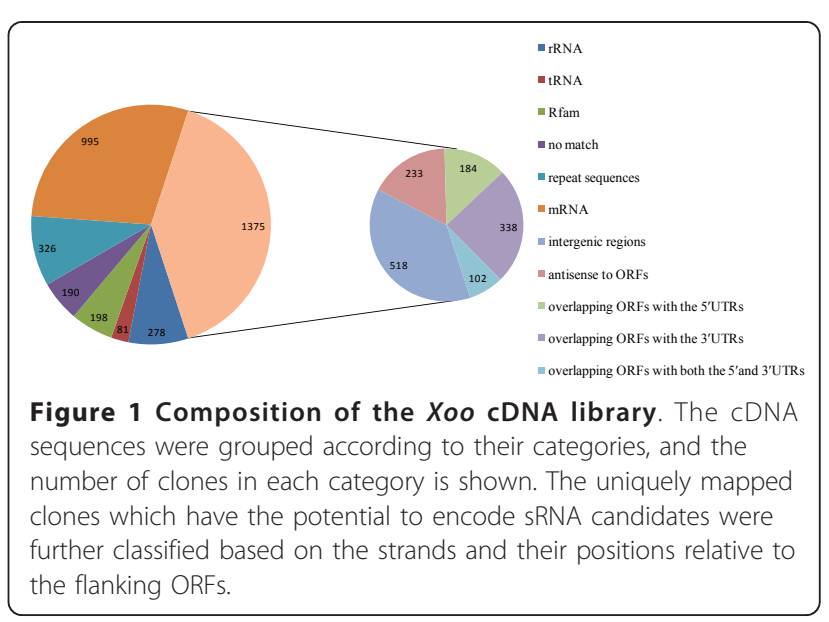


rRNA and tRNA sequences, respectively, since the designed probes used in the array analysis did not cover these regions. By comparing with the seven types of riboswitch elements and four classes of house-keeping sRNAs of Xoo reported in the Rfam database [34], 198 cloned sequences representing two riboswitch elements and three house-keeping sRNAs were found, suggesting the validity of our library. Among these reported sRNAs, the stable transfer-messenger RNA (tmRNA) had the highest clone frequency (Table 1).

Of the remaining 2,696 clones, 326 were mapped to multiple loci; thus their accurate genomic locations could not be determined without additional information. For the uniquely mapped clones, 995 of them were unambiguous fragments of mRNAs according to the open reading frame (ORF) annotations of the National Center for Biotechnology Information (NCBI). All these clones were then excluded from further investigation. The rest of the uniquely mapped 1,375 clones were categorized in detail. There were 518 (228 unique) clones derived from the IGRs and 233 (180 unique) cDNA clones were expressed from the opposite strand of ORFs. There were also 184 (153 unique) cDNA clones partially overlapped with the 5' untranslated regions (UTRs) and the coding sequences of ORFs. Since the majority of the transcription start sites of the protein coding genes were unknown in Xoo, these clones may represent partial mRNAs, riboswitches, or independent non-coding RNAs which may attenuate transcription or regulate translation initiation. In addition, 338 (219 unique) cDNA clones began within the ORFs and extended to the 3' UTRs of the ORFs; and 102 (83 unique) cDNA clones spanned the whole ORFs and overlapped with both the 5' and 3' UTRs. Detailed information on these sequences is listed in Additional file 2. We also used the Glimmer program [39] to screen whether any previously unannotated ORFs existed near or within these non-coding sequences. Sixty-eight putative ORFs were predicted by Glimmer and 28 predicted ORFs had canonical ribosome binding sites (RBS) [40]. A total of 23 (13 unique) cloned sequences overlapped with the predicted ORFs owing obvious RBS. The results are listed in Additional file 2. In brief, these results suggest that there are a large

Table 1 Riboswitch elements and house-keeping small RNAs identified in our library

\begin{tabular}{lc}
\hline RNAs & number of clones in library \\
\hline TPP & 1 \\
YybP-ykoY & 2 \\
$6 S$ & 26 \\
tmRNA & 151 \\
RNaseP_bact_a & 18 \\
\hline
\end{tabular}

number of putative non-coding RNAs which can be classified into various categories in the Xoo genome although experimental evidence is necessary to confirm them.

In addition to the cloning approach, we also applied the bacterial sRNA prediction program SIPHT (sRNA identification protocol using high-throughput technologies) to computationally predict sRNAs in the Xoo PXO99 ${ }^{A}$ genome [41]. A total of 269 sRNA candidates were predicted, of which 63 candidates were also identified by the cloning approach, thus were selected as sRNA candidates (Additional file 3 ). Both the direct cloning and the bioinformatic prediction approaches facilitated the detection of sRNAs in Xoo, providing us a large number of putative sRNA candidates for further studies. Recently, four novel sRNAs in the Xcc genome were reported [36], and three of them are conserved in the Xoo genome, of which, two sRNAs (sRNA-Xcc2, sRNA-Xcc4) were among our identified sRNA candidates, indicating that these two sRNAs may have important functions in Xanthomonas.

\section{Experimental verification and expression profiles of the sRNAs in Xoo}

Eight newly-identified sRNA candidates were selected for experimental confirmation. To investigate whether the bioinformatic prediction may miss real sRNAs, two cloned sequences (sRNA-Xoo2, sRNA-Xoo4) without prediction evidence were also selected for experimental confirmation. For these ten putative sRNA candidates, six of them were generated from the IGRs, and the other four candidates were from the UTR regions. Northern blot analyses were performed to verify these putative sRNA candidates using total RNA isolated from the wild-type strain at various growth phases. Eight sRNA candidates were repeatedly detected by Northern blot analysis and designated as sRNA-Xoo1, sRNA-Xoo2, sRNA-Xoo3, sRNA-Xoo4, sRNA-Xoo5, sRNA-Xoo6, sRNA-Xoo7 and sRNA-Xoo8, as showed in Figure 2. The sizes of the RNA molecules detected by Northern blotting were roughly in agreement with the length determined by the cloned or 5' RACE mapped sequences, which ranged from 78 nt to 365 nt (Table 2 and Additional file 4). The detailed information of these sRNAs is listed in Table 2.

The sRNA-Xoo2 and sRNA-Xoo7 are only conserved among Xoo strains and its closely related pathovar $X$. oryzae pv oryzicola, although their flanking genes are well conserved in other Xanthomonas species (Table 3). This results indicated that these two sRNAs may have originated recently and have species-specific functions. To the contrary, the other six sRNAs (sRNA-Xoo1, 3, 4, $5,6,8)$ are conserved among Xanthomonas (Table 3). To determine whether these eight sRNAs are newly 


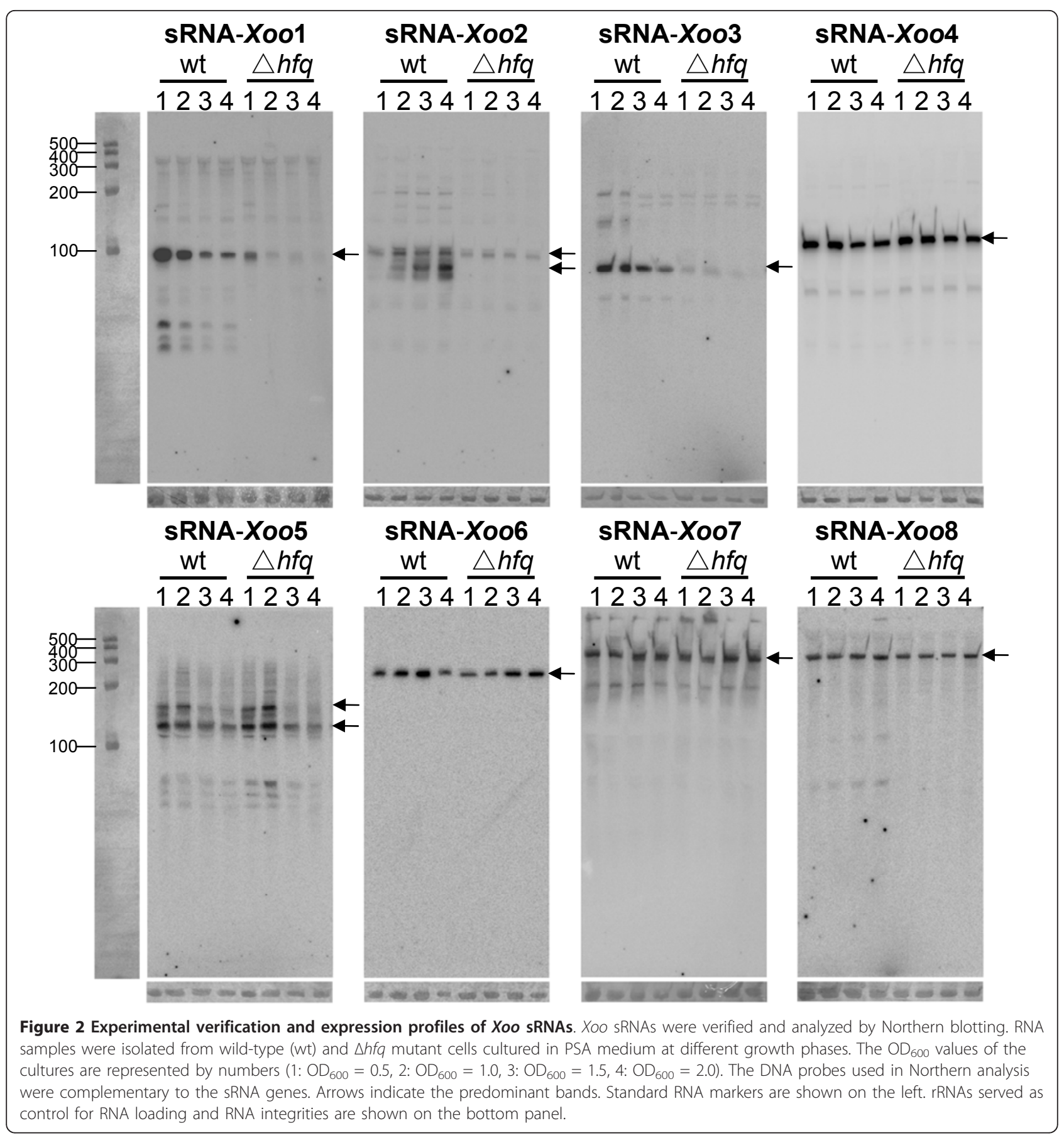

identified, a BLAST search was performed against the Rfam database http://www.sanger.ac.uk/Software/Rfam/ and small RNA database http://biobases.ibch.poznan.pl/ ncRNA/, none of these Xoo sRNA genes had similarities with any reported sRNAs. But it is possible that evolutionarily related sRNAs may also lack sequence similarity in different bacteria species. Then the conservation of their flanking genes was analyzed since sRNA and their flanking genes might be evolutionarily related but differed in the pace of diversity [19]. The blastx searches revealed that two flanking genes ( $l p x C$ and $f t s Z$ ) of sRNA-Xoo8 were highly conserved in many bacteria species although the intergenic region evolved rapidly. In Pseudomonas aeruginosa PAO1, a predicted sRNA annotated as PA4406.1 [42] was found between $l p x C$ and $f$ ts $Z$. These results indicated that sRNA-Xoo 8 may 
Table 2 Summarized information on sRNAs verified in this study

\begin{tabular}{|c|c|c|c|c|c|c|c|c|}
\hline sRNAs & strand & upstream gene & downstream gene & $5^{\prime}$ end & $3^{\prime}$ end & size $(\mathrm{nt})$ & No. & prediction \\
\hline sRNA-Xoo1 & + & PXO_02602 & PXO_02603 & $4451914^{a}$ & $4452016^{b}$ & $103^{\mathrm{c}} ; \sim 100^{\mathrm{d}}$ & 1 & NC-211 \\
\hline \multirow[t]{2}{*}{ sRNA-Xoo2 } & + & PXO_01687 & PXO_01686 & $3205976^{b}$ & $3206053^{b}$ & $78^{\mathrm{e}} \sim 100^{\mathrm{d}}$ & 1 & N \\
\hline & & & & & & $\sim 85^{\mathrm{d}}$ & & \\
\hline sRNA-Xoo3 & + & PXO_03614 & PXO_03613 & $250669^{a}$ & $250761^{b}$ & $93^{c} ; \sim 80^{d}$ & 2 & NC-137 \\
\hline sRNA-Xoo4 & - & PXO_05774 & PXO_02847 & $4955974^{a}$ & $4955830^{b}$ & $145^{c} ; \sim 150^{d}$ & 99 & N \\
\hline \multirow[t]{2}{*}{ sRNA-Xoo5 } & + & PXO_00354 & PXO_00353 & $2045785^{a}$ & $2045908^{b}$ & $124^{c} ; \sim 130^{d} ;$ & 2 & $N C-123$ \\
\hline & & & & & & $\sim 100^{d}$ & & \\
\hline sRNA-Xoo6 & - & PXO_03506 & PXO_03507 & $5217958^{b}$ & $5217771^{b}$ & $188^{\mathrm{e}} \sim 250^{\mathrm{d}}$ & 7 & NC-248 \\
\hline sRNA-X007 & - & PXO_04745 & PXO_04746 & $1379160^{\mathrm{a}}$ & $1378796^{\mathrm{b}}$ & $365^{c} ; 300^{d}$ & 1 & NC-40 \\
\hline sRNA-Xoo8 & + & PXO_04362 & PXO_04361 & $1067954^{b}$ & $1068276^{b}$ & $323^{e} ; \sim 300^{d}$ & 6 & NC-87 \\
\hline
\end{tabular}

a Ends determined by 5' RACE mapping (5' RACE results are given in Additional file 4).

${ }^{b}$ Ends determined by cloned sequences.

'Size determined by RACE analysis.

${ }^{\mathrm{d}}$ Size observed in Northern blot analysis.

${ }^{\text {e}}$ Size determined by cloned sequences.

No.: number of cloned sequences in our cDNA library.

be related to PA4406.1 evolutionarily. For the other seven Xoo sRNAs, evolutionarily related sRNAs have not been identified in other bacteria species, indicating that they are newly identified sRNAs in bacteria.

Among the eight experimentally verified sRNAs, two sRNAs (sRNA-Xoo2, sRNA-Xoo4) were overlooked in our bioinformatic search, probably due to their close proximity to the adjacent coding sequences, whereas the clone-based method enabled us to identify these two sRNAs successfully (Table 2). Among the eight sRNAs, half of them were encoded within the IGRs, while the other four sRNAs overlapped with adjacent genes (Figure 3). In addition, the other two sRNA candidates (PXO_03433-03434 and PXO_00355-00356) which were oriented in IGRs could not be detected by Northern blot analysis under the test conditions. These candidates either showed multiple faint bands without predominant bands or failed to be detected completely. We considered these two sRNA candidates to be likely transcribed at extremely low levels or not transcribed at all under the tested conditions.
The expression profiles of these identified sRNAs were also revealed by Northern blotting. Two sRNAs (sRNAXoo2, sRNA-Xoo5) showed size variations, indicating the presence of a precursor or processing event according to the growth phases. For sRNA-Xoo2, two transcripts were detected. The abundance and the relative ratio between these two transcripts varied with the growth phase, as the abundance of the longer transcript decreased when entering the stationary phase, whereas that of the shorter one increased at the same time. The shorter transcript may be a processed product or an active version of the longer one. For sRNA-Xoo5, two transcripts were detected in the early growth phases, while in the later growth phases only the short one could be detected. These results indicated that the expression and function of some Xoo sRNAs were under strict regulation during the life span of these bacteria.

For the other six sRNAs (sRNA-Xoo1, 3, 4, 6, 7, 8), a single major band was detected. Among these six sRNAs, the expression of two sRNAs (sRNA-Xoo1, sRNA-Xoo3) peaked in the early growth phases, but

Table 3 Conservation of the identified sRNAs in closely related species

\begin{tabular}{|c|c|c|c|c|c|c|c|c|c|c|}
\hline \multirow{2}{*}{$\begin{array}{l}\text { species } \\
\text { strain }\end{array}$} & \multirow{2}{*}{$\begin{array}{c}\text { Xooc } \\
\text { BLS256 }\end{array}$} & \multicolumn{3}{|c|}{$X c c$} & \multicolumn{2}{|c|}{ Xoo } & \multirow{2}{*}{$\begin{array}{c}X c v \\
85-10\end{array}$} & \multirow{2}{*}{$\begin{array}{l}X a c \\
306\end{array}$} & \multirow[b]{2}{*}{$9 a 5 c$} & \multirow{2}{*}{$\begin{array}{c}X f \\
\text { Temecule1 }\end{array}$} \\
\hline & & 8004 & АTCC33913 & B100 & KACC10331 & MAFF311018 & & & & \\
\hline sRNA-Xoo1 & $\mathrm{N}$ & $91 \%$ & $91 \%$ & $91 \%$ & $100 \%$ & $100 \%$ & $95 \%$ & $95 \%$ & $\mathrm{~N}$ & $\mathrm{~N}$ \\
\hline sRNA-Xoo2 & $95 \%$ & $\mathrm{~N}$ & $\mathrm{~N}$ & $\mathrm{~N}$ & $100 \%$ & $100 \%$ & $\mathrm{~N}$ & $\mathrm{~N}$ & $\mathrm{~N}$ & $\mathrm{~N}$ \\
\hline sRNA-Xoo3 & $98 \%$ & $94 \%$ & $94 \%$ & $94 \%$ & $100 \%$ & $100 \%$ & $96 \%$ & $95 \%$ & $\mathrm{~N}$ & $\mathrm{~N}$ \\
\hline sRNA-Xoo4 & $95 \%$ & $92 \%$ & $92 \%$ & $92 \%$ & $100 \%$ & $100 \%$ & $93 \%$ & $93 \%$ & $\mathrm{~N}$ & $\mathrm{~N}$ \\
\hline sRNA-Xoo5 & $99 \%$ & $94 \%$ & $94 \%$ & $94 \%$ & $99 \%$ & $100 \%$ & $99 \%$ & $98 \%$ & $\mathrm{~N}$ & $N$ \\
\hline sRNA-Xoo6 & $96 \%$ & $92 \%$ & $92 \%$ & $92 \%$ & $100 \%$ & $99 \%$ & $94 \%$ & $94 \%$ & $\mathrm{~N}$ & $\mathrm{~N}$ \\
\hline sRNA-X007 & $99 \%$ & $\mathrm{~N}$ & $\mathrm{~N}$ & $\mathrm{~N}$ & $100 \%$ & $99 \%$ & $\mathrm{~N}$ & $\mathrm{~N}$ & $\mathrm{~N}$ & $\mathrm{~N}$ \\
\hline sRNA-Xoo8 & $97 \%$ & $84 \%$ & $84 \%$ & $84 \%$ & $100 \%$ & $100 \%$ & $88 \%$ & $89 \%$ & $\mathrm{~N}$ & $\mathrm{~N}$ \\
\hline
\end{tabular}

Xooc: Xanthomonas oryzae pv oryzicola; Xcc: Xanthomonas campestris pv. campestris; Xoo: Xanthomonas oryzae pv. oryzae; Xcv: Xanthomonas campestris pv. vesicatoria; Xac: Xanthomonas axonopodis pv. citri; Xf: Xylella fastidiosa; N: no similar sequence. 


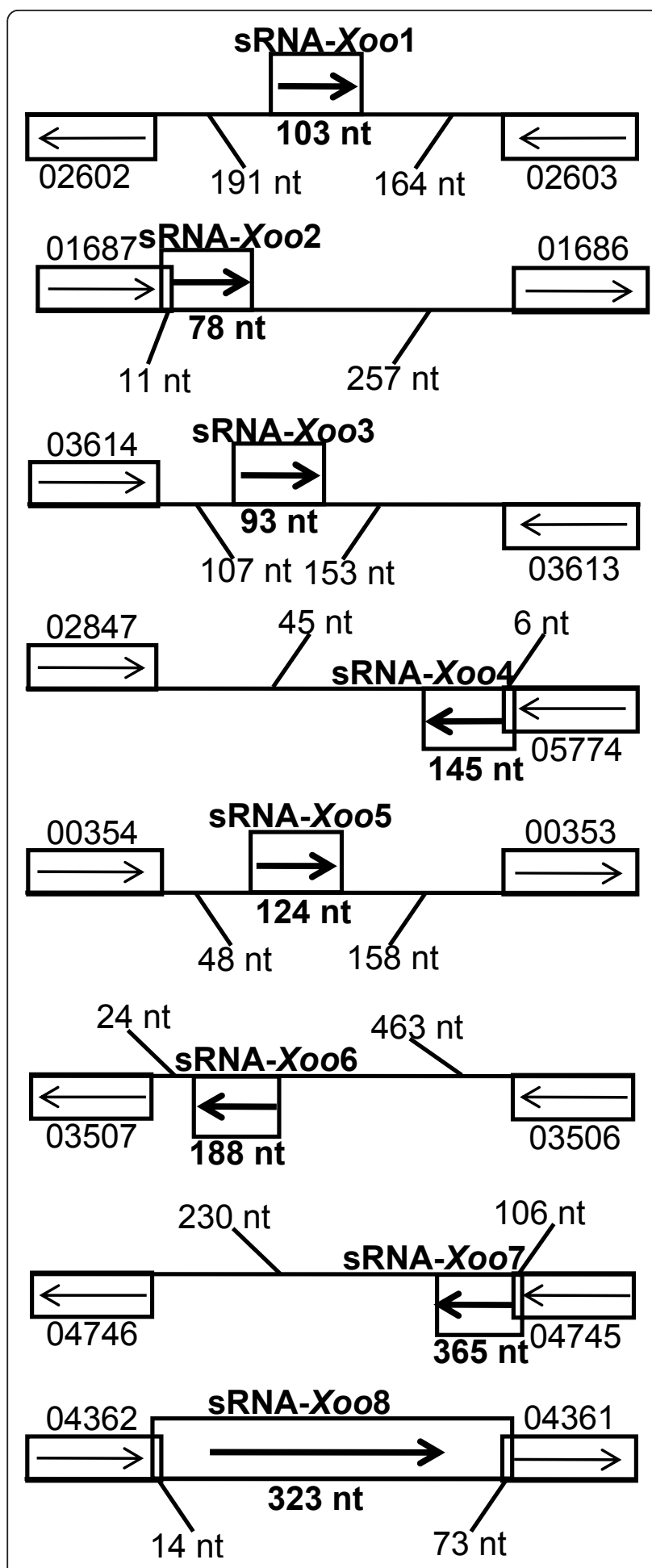

Figure 3 Schematic representation of the genomic positions of the verified sRNA genes. The genomic positions of the eight SRNA genes in the Xoo strain PXO99 are shown. The orientation of each sRNA gene and the flanking ORFs (the gene ID is listed) are indicated by the arrow. The lengths of the sRNA genes, the distances between the sRNA gene and its flanking genes are also indicated. decreased around entering of the later exponential phase and the entire stationary phase; the other four sRNAs (sRNA-Xoo4, sRNA-Xoo6, sRNA-Xoo7, sRNA-Xoo8) showed constant expression levels in different growth phases. Of note, the expression levels of sRNA-Xoo4 were dramatically higher than the other sRNAs throughout the growth phases, which was in agreement with its high clone frequency. sRNA-Xoo4 possessed distinct selfcomplementary secondary structure, resembling the SRP (signal-recognition particle) RNA. Such secondary structure may partially contribute to the stable abundance of this sRNA. An sRNA with similar secondary structure was also reported in Streptomyces coelicolor [43]. The secondary structures of these identified sRNAs predicted by MFOLD program are showed in Additional file 5 .

\section{Hfq-dependent sRNAs}

Hfq is a RNA-binding protein and plays important roles in sRNA functions. Nearly half of the sequenced eubacterial genomes encode an Hfq homolog [21]. Using the Hfq sequence of $E$. coli, we identified a single copy gene encoding highly conserved Hfq protein in the Xoo PXO99 $^{\mathrm{A}}$ genome using BlastP search (score $=135$, evalue $=4 \mathrm{e}-33$ ). To assess whether $h f q$ was independently transcribed or transcribed as part of an operon, we performed RT-PCR using primers spanning the two adjacent genes. The result shows that $h f q$ is co-transcribed with its adjacent genes (PXO_00156 and PXO_00154) as an operon (Additional file 6).

To investigate the functions of Xoo Hfq protein, we constructed a non-polar, in-frame deletion mutant of $h f q(\Delta h f q)$. When cultured in rich PSA medium, the $\Delta h f q$ mutant showed a longer lag phase and reached the stationary phase at a lower optical density compared with the wild-type strain (Additional file 7), whereas no difference was detected when cultured in minimal medium MMX. Genetic complementation of $h f q$ using a recombinant pHM1 plasmid, in which a full-length $h f q$ gene was subjected to the control of a plac promoter, restored the growth of $\Delta h f q$ in PSA medium (Additional file 7). Although deletion of $h f q$ in several animal bacteria pathogens resulted in attenuation of virulence [44], mutation in $h f q$ in Xoo PXO99 did not cause detectable decrease of virulence after inoculation into the host plant rice cultivar IR24. Both the wild-type and $\Delta h f q$ mutant strains caused blight disease symptoms on rice leaves and had no difference in mean lesion lengths. These results suggested that Hfq is not involved in the virulence of Xoo under the experimental conditions used in this study, and its biological roles need to be investigated in further studies.

Successful construction of the $h f q$ mutant provided us the opportunity to assess the relationship between $\mathrm{Hfq}$ 
and the confirmed sRNAs in Xoo. By Northern blot hybridization, the expression level of the identified sRNAs in the $\Delta h f q$ mutant was compared to the wildtype strain grown under identical experimental conditions (Figure 2). The expressions of three sRNAs (sRNA-Xoo1, 2, 3) were affected in the $\Delta h f q$ mutant. The transcriptional levels of sRNA-Xoo1 and sRNAXoo3 decreased significantly throughout the growth phases in the $\Delta h f q$ mutant, indicating that the expression or stability of these sRNAs was completely dependent on Hfq. The sRNA-Xoo1 was predicted and annotated as a riboswitch previously [41]. However, based on its altered expression pattern in the $\Delta h f q$ mutant, we would argue that sRNA-Xoo1 is an Hfqdependent sRNA. Northern blotting of sRNA-Xoo 2 revealed two unambiguous bands, suggesting a possible presence of post-transcriptional modification of the sRNA-Xoo 2 primary transcript. The expression profile of sRNA-Xoo 2 altered dramatically in the $\Delta h f q$ mutant. The disappearance of the shorter transcript indicates that the putative processing step of sRNA-Xoo2 is Hfqdependent or the shorter form of sRNA-Xoo2 is particularly unstable in the $\Delta h f q$ mutant. The other five sRNAs are likely to be $\mathrm{Hfq}$ independent as their expression remained unchanged in the $\Delta h f q$ mutant. The functions of these $\mathrm{Hfq}$ independent sRNAs remain to be elucidated.

\section{Functional characterization of sRNAs}

To investigate the biological functions of these experimentally identified sRNAs, we successfully created sRNA-deleted mutants of the experimentally verified sRNAs (except for sRNA-Xoo8) without affecting the expression of the flanking genes. The correct deletion of each sRNAs-coding gene was confirmed by sequencing. These sRNA-deleted mutants were then characterized for changes in phenotype. No significant differences between the $\Delta$ sRNA mutants and the wild-type strain were observed in growth rates when the bacteria were grown in both the rich medium (PSA) and minimum medium (MMX), virulence and activities of extracellular enzymes (including extracellular protease, amylase and cellulose). The lack of phenotypic changes of these seven sRNA-deleted mutants may be ascribed to either the minor regulatory roles or the functional redundancy of the identified Xoo sRNAs. Further study on these sRNAs by other approaches such as overexpression may provide us some clues into the nature of their functions.

Targets identification is a key step to elucidate the functions of these experimentally verified Xoo sRNAs. It has been demonstrated that trans-encoded sRNAs usually regulate their target genes via short, discrete and incomplete complementary base pairing, making it difficult to predict the target genes for bacterial sRNAs. In order to identify their potential targets and regulatory roles, three sRNAs (sRNA-Xoo1, sRNA-Xoo3 and sRNAXoo4) were selected for further proteomic analysis. Although the proteins identified via two-dimensional gel electrophoresis (2-DE) analysis may either be directly or indirectly regulated by sRNAs, this analysis would provide us some insights to understand the regulatory functions of these sRNAs.

For the proteomic analysis, total proteins from the wild-type strain and sRNA mutants were harvested in the stationary stage $\left(\mathrm{OD}_{600}=1.5\right)$ which was consistent with the culture conditions used to clone the sRNA candidates. After 2-DE separation, protein spots that showed more than 1.4-fold change in relative abundance between the wild-type and mutant were selected for mass spectrometry (MS) identification and further analysis. The 2-DE analysis results of the three sRNAs are described separately below.

\section{sRNA-Xoo 1}

As shown in Figure 3, this Hfq-dependent sRNA is encoded by the intergenic region between PXO_02602 (encoding a transcriptional regulatory factor) and PXO_02603 (thiC, encoding a thiamine biosynthesis protein). Based on the distinct expression pattern of sRNA-Xoo1 in the Dhfq mutant and the changes in expression levels during different growth phases in the wild-type strain, we believe that sRNA-Xoo1 has important regulatory functions. The 2-DE maps of the DsRNA-Xoo1 mutant and wild-type strain are shown in Figure 4. The detailed information on the differentially expressed proteins including functional categories is listed in Table 4.

We identified altogether 6 and 16 proteins that were up or down-regulated in the DsRNA-Xoo1 mutant, respectively (Table 4). Two important aspects can be defined from these differentially expressed proteins. (1) Most of these proteins participate in amino acid metabolism. Among them, it is notable that the phosphoenolpyruvate (PEP) synthase was down-regulated 6.36-fold compared to the wild-type. PEP is involved in important metabolic pathways such as glycolysis and gluconeogenesis, and in synthesis of chorismate through the shikimate pathway, which is critical for biosynthesis of aromatic amino acids such as phenylalanine, tryptophan and tyrosine. Thus, we concluded that sRNA-Xoo1 may be a positive regulator of aromatic amino acids synthesis through direct or indirect promotion of PEP synthase activity. (2) Proteins related to material transport were also regulated in the DsRNA-Xoo1 mutant. The most substantially down-regulated protein was a putative $A B C$ transporter that can transport proteins, polysaccharides or low-molecular weight materials, suggesting that sRNA-Xoo1 is also associated with secretion, although the secreted substrate remains unknown. 

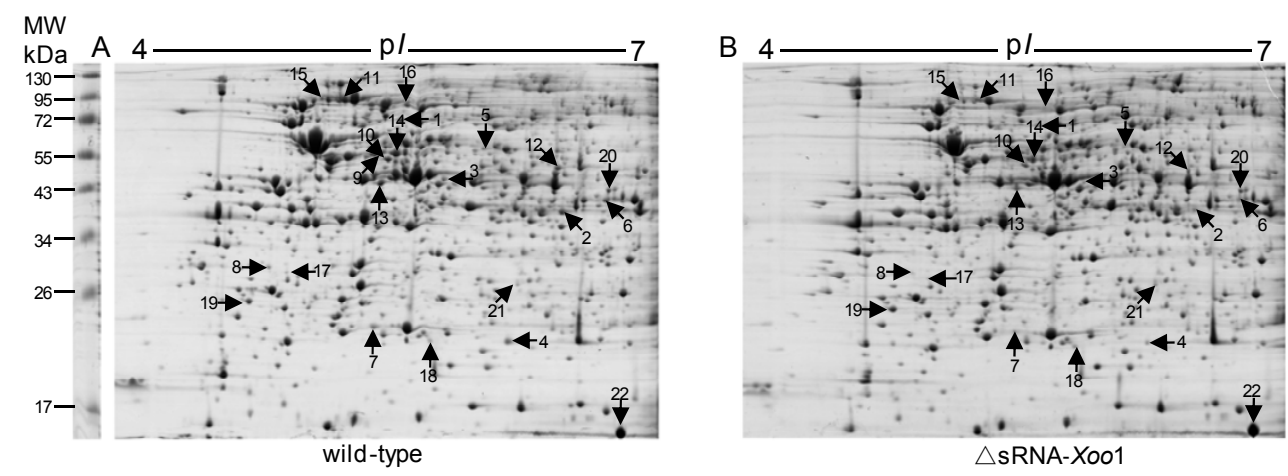

Figure 4 2-DE maps of total proteins from Xoo wild-type strain PXO99 (A) and $\triangle$ sRNA-Xoo1 mutant (B). Protein spots indicated by numbers are the differentially expressed proteins between the wild-type and $\triangle$ SRNA-Xoo1 mutant. All the labelled spots were identified by MS.

\section{sRNA-Xoo3}

This Hfq-dependent sRNA is expressed from the IGR which is 353 bp in length. Two genes (PXO_03613 and PXO_03614) flanking sRNA-Xoo3 are in different orientations. The expression levels of this sRNA changed according to different growth phases in the wild-type and dramatically decreased in the $\Delta h f q$ mutant, suggesting that it harbours important regulatory functions.

Table 4 Differentially expressed proteins in $\triangle$ SRNA-Xoo1 identified by MS

\begin{tabular}{|c|c|c|c|c|c|c|c|}
\hline $\begin{array}{l}\text { Spot } \\
\text { ID }\end{array}$ & protein name & functions & $\begin{array}{l}\text { NCBI acc. } \\
\text { no. }\end{array}$ & $\begin{array}{l}\text { mascot } \\
\text { score }\end{array}$ & $\begin{array}{l}\text { Sequence } \\
\text { coverage }\end{array}$ & $\begin{array}{l}\text { theoretical } \\
\mathrm{MW}(\mathrm{Da}) / \mathrm{pl}\end{array}$ & Ratio \pm SD \\
\hline \multicolumn{8}{|c|}{ Down-regulated protein spots in sRNA-Xoo1 mutant } \\
\hline B1 & $\begin{array}{l}\text { putative ABC transporter ATP-binding } \\
\text { protein }\end{array}$ & transport & PXO_04409 & 448 & $56 \%$ & $61740 / 5.37$ & $11.57 \pm 4.83$ \\
\hline B2 & $\begin{array}{l}\text { glyceraldehyde-3-phosphate } \\
\text { dehydrogenase }\end{array}$ & metabolism & PXO_02308 & 529 & $69 \%$ & $36134 / 6.35$ & $4.75 \pm 0.57^{* *}$ \\
\hline B3 & argininosuccinate synthase & amino acid biosynthesis & PXO_00352 & 769 & $67 \%$ & $45217 / 5.66$ & $3.25 \pm 0.56$ \\
\hline B4 & tryptophan repressor binding protein & amino acid metabolism & PXO_03044 & 438 & $52 \%$ & $20167 / 6.05$ & $2.83 \pm 0.18^{* *}$ \\
\hline B5 & $\begin{array}{l}\text { 3-isopropylmalate isomerase large } \\
\text { subunit }\end{array}$ & amino acid biosynthesis & PXO_02613 & 314 & $42 \%$ & $51984 / 5.68$ & $1.86 \pm 0.21^{* *}$ \\
\hline B6 & $\mathrm{N}$-acetylornithine carbamoyltransferase & amino acid biosynthesis & PXO_00353 & 314 & $65 \%$ & $37582 / 6.07$ & $1.7 \pm 0.19^{* *}$ \\
\hline B7 & superoxide dismutase & oxidation reduction & PXO_00389 & 343 & $68 \%$ & $22703 / 5.47$ & $1.42 \pm 0.03^{* *}$ \\
\hline B8 & septum site-determining protein MinD & replication & PXO_04464 & 435 & $46 \%$ & $28837 / 5.21$ & $1.57 \pm 0.19^{* *}$ \\
\hline B9 & N-ethylammeline chlorohydrolase & metabolism & PXO_00380 & 263 & $62 \%$ & $48943 / 5.19$ & ND \\
\hline B10 & 2-isopropylmalate synthase & amino acid biosynthesis & PXO_02609 & 694 & $71 \%$ & $53421 / 5.54$ & $1.54 \pm 0.15^{* *}$ \\
\hline B11 & translation elongation factor $\mathrm{G}$ & $\begin{array}{l}\text { transcription and } \\
\text { translation }\end{array}$ & PXO_04525 & 642 & $58 \%$ & $75924 / 5.09$ & $4.82 \pm 0.42^{* *}$ \\
\hline B12 & dihydrolipoamide dehydrogenase & amino acid metabolism & PXO_01196 & 582 & $67 \%$ & $50445 / 5.98$ & $2.29 \pm 0.54$ \\
\hline B13 & $\mathrm{N}$-acylglucosamine 2-epimerase & metabolism & PXO_01231 & 811 & $77 \%$ & $46884 / 5.27$ & $2.23 \pm 0.34^{* *}$ \\
\hline B14 & ATP synthase subunit alpha & transport & PXO_03111 & 777 & $48 \%$ & $55391 / 5.38$ & $2.23 \pm 0.5$ \\
\hline B15 & phosphoenolpyruvate synthase & Pyruvate metabolism & PXO_00922 & 622 & $48 \%$ & $86689 / 5.16$ & $6.36 \pm 1.69$ \\
\hline B16 & $\begin{array}{l}\text { Polyribonucleotide } \\
\text { nucleotidyltransferase }\end{array}$ & metabolism & PXO_01307 & 729 & $55 \%$ & $75502 / 5.47$ & $5.39 \pm 0.93$ \\
\hline \multicolumn{8}{|c|}{ Up-regulated protein spots in $\triangle$ sRNA-Xoo1 mutant } \\
\hline B17 & pyrroline-5-carboxylate reductase & amino acid metabolism & PXO_01991 & 301 & $51 \%$ & $29364 / 4.93$ & $1.48 \pm 0.07^{* *}$ \\
\hline B18 & peptide deformylase & protein synthesis & PXO_04055 & 379 & $55 \%$ & $17129 / 5.29$ & $1.45 \pm 0.02^{* *}$ \\
\hline B19 & outer membrane protein & transport & PXO_03097 & 343 & $32 \%$ & $23707 / 5.27$ & $1.43 \pm 0.04^{* *}$ \\
\hline B20 & Chaperone protein dnaJ & DNA replication & PXO_01186 & 702 & $64 \%$ & $41079 / 6.21$ & $1.52 \pm 0.14^{* *}$ \\
\hline B21 & hydrolase, carbon-nitrogen family & metabolism & PXO_06060 & 526 & $68 \%$ & $30229 / 5.89$ & $1.57 \pm 0.12^{* *}$ \\
\hline B22 & hypothetical protein & hypothetical protein & PXO_01766 & 635 & $75 \%$ & $16502 / 6.3$ & $1.41 \pm 0.01$ \\
\hline
\end{tabular}

ND: not detectable in the 2-DE maps of wild-type or $\triangle$ sRNA-Xoo1 mutant. SD: Standard Deviation. Statistical significance was determined using Student's twotailed $t$ test for unpaired means $P<0.05, P<0.01^{* *}$. 
The 2-DE map of the $\triangle$ sRNA-Xoo3 mutant is shown in Additional file $8 \mathrm{~A}$. From this mutant, 18 proteins with decreased expression and eight proteins with enhanced expression were identified. The down-regulated proteins can be classified into three major groups: oxidation reduction; response to stress and metabolism (Additional file 9). Of note, seven proteins including dehydrogenases, monooxygenase, reductase and superoxide dismutase which are related to the process of oxidation reduction were down-regulated in the DsRNA-Xoo3 mutant. Consistent with this observation, a protein related to ATP synthesis was up-regulated to 2.97 fold in the DsRNAXoo3 mutant. We hypothesized that this sRNA plays roles in regulating energy metabolism which is essential for the organism. The other seven up-regulated proteins in the DsRNA-Xoo3 mutant were assigned to various metabolic functions, including glutathione metabolism, fatty acid metabolism, lipopolysaccharide, and sucrose metabolism.

\section{sRNA-Xoo4}

The sRNA-Xoo4 is positioned in the IGR between PXO_05774 and PXO_02847 which is 184 bp in length, and the 5' end of sRNA-Xoo4 was mapped to the 3' end of the upstream gene PXO_05774, a hypothetical protein of unknown function. The lack of the promoter motifs in the upstream region of the sRNA-Xoo4 suggests that it may be processed from the upstream gene. The dramatically high expression levels and the specific single hairpin secondary structure suggested that sRNAXoo4 has some important functions.

The 2-DE map of the DsRNA-Xoo4 mutant is also shown in Additional file 8B. In the DsRNA-Xoo4 mutant, nine down-regulated proteins mainly impaired DNA replication, rRNA processing and metabolic processes. Since the inactivation of this SRNA affected the expression of genes involved in DNA replication, transcription and translation, it may be involved in some house-keeping like functions. Nine proteins with enhanced expression in the DsRNA-Xoo4 mutant mainly took part in transport and protein secretion. Membrane proteins such as the TonB receptor and outer membrane $(\mathrm{OM})$ protein were upregulated in the DsRNA-Xoo4 mutant, indicating that its function may also be related to material transport. Among these up-regulated proteins, a fimbrial assembly membrane protein (PXO_02354) was up-regulated 1.93-fold comparing with the wild-type. Fimbriae are filamentous appendages on the bacterial surface, which are anchored within the OM, regulating the protein secretion via close contact with the host cells. This result indicated that DsRNA-Xoo4 may play a role in pathogen-host recognition. Detailed information on the differentially expressed proteins is listed in Additional file 9.

In brief, the 2-DE results provided experimental evidence that the above three sRNAs in Xoo are involved in multiple physiological and biochemical processes. Because it was reported that one trans-encoded sRNA usually has many targets, it is possible that proteins identified by $2-\mathrm{DE}$ analysis may be directly regulated by the sRNA. However, indirect regulations could occur in the null mutant of sRNA. Further analysis should clarify which genes are the real and direct targets of the sRNAs. Therefore, the differentially expressed proteins characterized by the 2-DE approach in this work were useful for providing potential targets of the identified sRNAs in $X o o$, and these findings provide the initial step toward dissecting their functions.

\section{Analysis of cis-encoded sRNA candidates}

The detection of the 2 cloned sequences without sRNA prediction support by Northern blotting suggested that our sRNA selection criteria were too strict and had excluded some authentic sRNAs. If consider all cloned non-coding short RNA sequences as sRNA candidates, a total of 180 non-redundant putative cis-encoded sRNAs were cloned. Recent transcriptomic analyses have revealed that cis-encoded antisense sRNAs exist generally in bacterial cells, albeit their metabolic processes and functional roles remain to be investigated [29]. Among the 180 non-redundant putative cis-encoded sRNAs candidates in our library, only 16 (8.9\%) were generated by transposons or insertion elements, whereas all the other candidates were transcribed from nontransposable regions. Although the full-length sequences of these sRNA candidates were unclear, alignments showed that 108 of them were complementary to the central regions of potential target mRNAs; 44, 16 and 12 sequences were complementary to, respectively, the 3 ' region, the 5' region or the entire sequence of their target mRNAs and overlapped with the adjacent UTRs (Additional file 10). The difference in base pairing locations may reflect the distinct regulatory mechanisms of these putative sRNAs.

As revealed in other bacteria, cis-encoded antisense RNA is also prevalent [30]. For example, in the human gastric pathogen Helicobacter pylori, massive parallel cDNA sequencing found that $46 \%$ of all ORFs have at least one antisense transcriptional start site [45]. Therefore, the identification of such a large number of cisencoded antisense sRNA candidates in Xoo suggested that this type of sRNA may take part in regulating various cellular processes. The putative target genes of the above mentioned cis-encoded sRNA candidates could be classified into diverse functional categories (Additional file 10). Eight TonB-dependent receptor genes were predicted to be targeted by cis-encoded antisense sRNAs, constituting the largest functional group among the virulence-associated genes. TonB-dependent receptor genes are required for the bacterial uptake of iron that 
is usually limited in the host organism [46], therefore play an important role for the survival of bacteria within host tissues or cells [47]. In previous studies, it was revealed that several TonB-dependent receptors, such as IroN, BfeA and BtuB are involved in pathogenesis of $X c c$, supporting that iron-uptake is also critical for the pathogenicity of Xanthomonas spp. [48,49]. However, in $X o o$, aside from the regulatory protein Fur (ferric iron uptake regulator) [50], little is known about how the iron-uptake systems are modulated and involved in virulence. In $E$. coli, the small RNA RyhB has been reported to be essential for iron metabolism $[51,52]$ and intracellular iron homeostasis by regulating genes responsible for siderophore and cysteine biosynthesis $[53,54]$, providing evidence that small RNA also takes part in regulation of iron uptake in bacteria. Consequently, further study on the function of the above identified TonB-dependent receptors and the corresponding cis-encoded sRNA candidates will promote our understanding in this field.

\section{Conclusions}

Through cloning and bioinformatic methods in the present study, eight sRNAs in Xoo were experimentally confirmed among a large number of sRNA candidates, three of which were determined to be Hfq-dependent sRNAs. We provided experimental evidence to clarify that these sRNAs play roles in diverse important biological pathways in Xoo. Although the direct targets will need to be identified to further dissect the function of these sRNAs, the differentially expressed proteins revealed by proteomic analysis in our study provided valuable hints and served as a starting point for unraveling the sRNA mediated regulatory networks in Xoo.

\section{Methods}

\section{Bacterial strains and culture conditions}

All bacterial strains used in this study are listed in Additional file 11. Xanthomonas oryzae pv. oryzae PXO99 was routinely cultured in rich medium PSA (tryptone, $10 \mathrm{~g} / \mathrm{L}$; sucrose, $10 \mathrm{~g} / \mathrm{L}$; glutamic acid, $1 \mathrm{~g} / \mathrm{L} ; \mathrm{pH}$ 7.0) or in minimal medium MMX (sodium citrate, $1.0 \mathrm{~g} / \mathrm{L}$; $\mathrm{K}_{2} \mathrm{HPO}_{4}, 4 \mathrm{~g} / \mathrm{L} ; \mathrm{KH}_{2} \mathrm{PO}_{4}, 6 \mathrm{~g} / \mathrm{L} ;\left(\mathrm{NH}_{4}\right)_{2} \mathrm{SO}_{4}, 2 \mathrm{~g} / \mathrm{L}$; $\mathrm{MgSO}_{4} \cdot 7 \mathrm{H}_{2} \mathrm{O}, 0.2 \mathrm{~g} / \mathrm{L}$; and glucose, $\left.5 \mathrm{~g} / \mathrm{L} ; \mathrm{pH} 7.0\right)$ at $28^{\circ}$ C. E. coli strain DH10B ${ }^{\mathrm{TM}^{\mathrm{N}}}$ was used in library and plasmid constructions, and clones were grown in LuriaBertani broth at $37^{\circ} \mathrm{C}$. Antibiotics were added to media when required at final concentrations of $50 \mu \mathrm{g} / \mathrm{mL}$ of kanamycin for both Xoo and E. coli; and at $100 \mu \mathrm{g} / \mathrm{mL}$ of ampicillin for E. coli.

\section{Construction and analysis of the CDNA library}

The methods used to clone the small RNAs in this study was based on a published protocol [55]. Cultures of Xoo were harvested at $\mathrm{OD}_{600}$ of 1.5 . Total RNA was extracted using the TRIzol reagent (Invitrogen), and 300 $\mu \mathrm{g}$ RNA pre-treated with RQ1 RNase-free DNase I (Promega) was separated on denaturing $8 \%$ polyacrylamide gels (7 M urea). RNAs ranging from 50 to 500 nt were eluted and ethanol precipitated [56]. The size selected RNAs were 3' tailed by CTP and poly (A) polymerase and then reverse transcribed by oligo (G) primer (see Additional file 12 for sequence) and SuperScript ${ }^{\mathrm{TM} I I}$ Reverse Transcriptase (Invitrogen). Subsequently, cDNAs were cloned into the pSPORT1 vector (Invitrogen) and transformed into E. coli strain $\mathrm{DH}_{10 \mathrm{~B}^{\mathrm{TM}}}$ competent cells.

Initially, 192 clones were sequenced, which allowed us to identify the abundant rRNA and tRNA fragments in the library. Specific probes (Additional file 12 for sequence) were designed based on these sequences to deplete the highly abundant RNA species. Pre-screening was performed as follows: cDNA inserts of individual clones were amplified using the M13 forward and M13 reverse primers, and then the PCR products were purified and spotted in high-density arrays. Hybridization was performed using specific probes. Clones showing the lowest signals were selected to sequence. Bioinformatic analysis was performed by first excluding sequences representing rRNA, tRNA and sRNAs reported in Rfam. The remaining sequences were then mapped to the Xoo PXO99 ${ }^{\mathrm{A}}$ genome by BLAST searches. The putative sRNA genes were further categorized based on the strands and positions relative to the flanking ORFs. Non-coding RNA structures were predicted using MFOLD version 3.0. VIMSS operon prediction was used to predict the operon organization in Xoo PXO99 ${ }^{\mathrm{A}}$. Sequences for sRNA-Xoo1-8 were deposited in GenBank with accession numbers from HQ890319 to HQ890326.

\section{RNA analysis}

Total RNA was extracted from liquid cultures of $\mathrm{Xoo}$ at different $\mathrm{OD}_{600}$ values using TRIzol reagent. RNA samples were quantified using a NanoDrop ND-1000 spectrophotometer (Thermo, USA). RNA $(30 \mu \mathrm{g})$ were denatured for $5 \mathrm{~min}$ at $95^{\circ} \mathrm{C}$ in Gel Loading Buffer II (Ambion), then separated on denaturing $8 \%$ polyacrylamide gels and transferred to Hybond $-\mathrm{N}^{+}$membrane (Amersham) by electro-blotting. RNAs were immobilized to the membrane by UV cross-linking. Before hybridization the membranes were stained with methylene blue to check the integrity of RNA and also ensure uniform loading of RNA. The DNA oligonucleotide probes (see Additional file 12 for sequences) were labelled with $\left[\gamma-{ }^{32} \mathrm{P}\right]$ ATP using T4 polynucleotide kinase (NEB). Membranes were pre-hybridized in Church and Gilbert buffer [57] at $42^{\circ} \mathrm{C}$ for 2 hours and 
hybridized at $42^{\circ} \mathrm{C}$ for 16 hours. The membranes were washed with $2 \times \mathrm{SSC}, 0.1 \% \mathrm{SDS} ; 1 \times \mathrm{SSC}, 0.1 \% \mathrm{SDS}$ and $0.1 \times \mathrm{SSC}, 0.1 \% \mathrm{SDS}$ for $20 \mathrm{~min}$ at $42^{\circ} \mathrm{C}$ sequentially. Hybridization signals were visualized on a phosphorimager. Northern blots for all detectable sRNAs were confirmed for three biological repeats. All RNA samples of the wild-type strain and Dhfq mutant were treated similarly throughout the experimental steps. Thus any differences observed between the wild-type and Dhfq mutant could be attributed to changes in the expression of the sRNAs.

For reverse transcription (RT)-PCR analysis, $2 \mu \mathrm{g}$ of total RNA pre-treated with RQ1 RNase-free DNase I (Promega) were reverse transcribed using random hexamer primers and SuperScript ${ }^{\mathrm{TM}}$ II Reverse Transcriptase (Invitrogen) as described by the manufacturer. For the negative control, the same RNA samples were also incubated in the same system only without reverse transcriptase. All reactions were performed in $25 \mu \mathrm{L}$ volumes.

For the 5' RACE, mapping of the 5' end was carried out using the FirstChoice RLM-RACE kit (Ambion), following the manufacturer's instructions, but with modifications for bacterial RNA as outlined by Vogel [58]. The PCR products of 5' RACE were cloned into the pGEM$\mathrm{T}$ vector, and then the clones were sequenced and analyzed. Six to ten clones for each 5' RACE analysis were sequenced, and the farthest 5' end was regarded as the 5 ' end of the sRNA.

\section{Generation of mutant strains}

The $h f q$ and sRNA deletion strains were generated using a two-step homologous recombination strategy. The recombinant suicide vector derived from pk18mobsacB [59] was used to delete $h f q$ and sRNA coding genes in Xoo. Primers containing specific restriction enzyme sites were used to amplify the upstream and downstream fragments flanking $h f q$ and sRNAs coding genes are given in Additional file 12. PCR reactions were performed in $50 \mu \mathrm{L}$ volumes containing $30 \mathrm{ng}$ DNA of Xoo, $1 \times$ PCR buffer, $50 \mu \mathrm{M}$ each dNTPs, $0.2 \mu \mathrm{M}$ each primer, $1 \mathrm{mM} \mathrm{MgSO}_{4}$, and $1 \mathrm{U}$ of KOD-plus- polymerase (TOYOBO). The PCR was carried out using the following thermal cycling profile: $94^{\circ} \mathrm{C}$ for $4 \mathrm{~min}$, followed by 34 cycles of amplification $\left(94^{\circ} \mathrm{C}\right.$ for $30 \mathrm{~s}, 68^{\circ} \mathrm{C}$ for $1 \mathrm{~min}$ ) and finally $72^{\circ} \mathrm{C}$ for $5 \mathrm{~min}$. The PCR products were gel-purified and digested by relevant restriction enzymes, and purified again. The resulting two fragments were inserted into the pk 18 mobsacB vector digested with the appropriate restriction enzymes to create the suicide vector. The suicide vector was transformed into E. coli Top10. All recombinant vectors were verified by sequencing of the inserted fragments. For homologous recombination, the recombinant plasmids were extracted and electroporated into Xoo competent cells using a Micro-pulser set at $18 \mathrm{kVcm}^{-1}$, and the pulse time was approximately 0.3 to $0.4 \mathrm{~ms}$. Transformants were first selected on PSA plates containing kanamycin and then on PSA plates containing $10 \%$ sucrose to select double cross-over strains. Finally all mutants were verified by multiple PCR analysis and confirmed by sequencing.

\section{Plant inoculation and extracellular enzyme assays}

Two-month-old susceptible rice cultivar IR24 was used as the host plant. Bacteria were cultured to the early exponential phase, and the $\mathrm{OD}_{600}$ value was adjusted to 0.4. The leaves were clipped using sterile scissors which were dipped in the bacteria cultures. Lesion length was scored two weeks after inoculation as described by Dow [60]. The activities of three extracellular enzymes (protease, amylase, cellulose) were analyzed based on previously published methods [61]. PSA plates containing $1.5 \%$ skimmed milk, $0.1 \%$ soluble starch or $0.5 \%$ sodium carboxymethyl cellulose were used to test the protease, amylase and cellulose, respectively. Strains were cultured to $\mathrm{OD}_{600}$ of 0.1 , and then $1 \mu \mathrm{L}$ of the cultures were spotted onto the above mentioned plates. The plates were incubated at $28^{\circ} \mathrm{C}$ for 3-5 days before measuring the enzyme activities following the methods described by Tang et al. [61].

\section{Protein 2-DE analysis}

Bacterial cells were harvested and centrifuged at 8,000 $\mathrm{rpm}$ for $5 \mathrm{~min}$ at $4^{\circ} \mathrm{C}$. The cell pellets were washed twice with ice cold $10 \mathrm{mM}$ Tris ( $\mathrm{pH} 7.4$ ) buffer with $250 \mathrm{mM}$ sucrose. The cell pellets were resuspended with $4 \mathrm{~mL} 10 \mathrm{mM}$ Tris (pH 7.4) buffer containing PMSF $(40 \mu \mathrm{L}, 100 \mathrm{mM})$ and then sonicated for $15 \mathrm{~min}$ (cycles of $3 \mathrm{~s}$ on and $30 \mathrm{~s}$ off). Protein samples were then purified by phenol saturated with Tris- $\mathrm{HCl}(\mathrm{pH} \mathrm{8.6)}$ and precipitated with five volumes of $0.1 \mathrm{M}$ ammonium acetate in methanol at $-20^{\circ} \mathrm{C}$ overnight. After centrifugation at $12,000 \mathrm{rpm}$ for $20 \mathrm{~min}$ at $4^{\circ} \mathrm{C}$, the pellet was rinsed twice with ice-cold $0.1 \mathrm{M}$ ammonium acetate in methanol and twice with ice-cold $80 \%$ acetone. The airdried pellet was resuspended in isoelectric focusing (IEF) buffer containing $7 \mathrm{M}$ urea, $2 \mathrm{M}$ thiourea, 4\% CHAPS, 40 mM DTT, 2\% (v/v) IPG buffer ( $\mathrm{pH} 4-7)$. Protein concentration was determined using a 2-D Quant kit (GE Healthcare Life Sciences, NJ, USA). The supernatant containing the soluble protein fraction was immediately subjected to 2-DE for protein separation.

The 2-DE procedure was conducted according to a previously published protocol [62]. To obtain the highest possible resolution, $1 \mathrm{mg}$ proteins extracted from the related strains were separated by 2-DE using a nonlinear pH 4-7 IPG strips $(24 \mathrm{~cm})$ and SDS-PAGE, and each sample was analyzed in triplicate. Approximately 1,000 
\pm 50 spots could be detected on each gel. Protein amounts of the detected spots on normalized gels were quantified with ImageMaster 2D Platinum software, and the average intensities of the spots were measured.

Protein spots were excised from gels and washed twice with $400 \mu \mathrm{L}$ of $50 \mathrm{mM} \mathrm{NH}_{4} \mathrm{HCO}_{3}$ in $50 \%$ (V/V) ACN for 15 min to destain. The solution was then removed and $400 \mu \mathrm{L} \mathrm{100 \%} \mathrm{ACN} \mathrm{was} \mathrm{added} \mathrm{to} \mathrm{dehydrate} \mathrm{the} \mathrm{gel} \mathrm{pieces.}$ The gel pellets were vacuum dried and then rehydrated with $3 \mu \mathrm{L} 50 \mathrm{mM} \mathrm{NH}_{4} \mathrm{HCO}_{3}$ containing $20 \mathrm{ng} / \mu \mathrm{L}$ trypsin (Promega) at $4^{\circ} \mathrm{C}$ for $45 \mathrm{~min}$. An additional $3 \mu \mathrm{L}$ of $50 \mathrm{mM} \mathrm{NH}_{4} \mathrm{HCO}_{3}$ was added, and the reaction was incubated at $37^{\circ} \mathrm{C}$ overnight. The liquid was removed to a fresh tube, and the gel pellet was extracted again with $0.1 \%$ TFA in $50 \% \mathrm{ACN}$ at $37^{\circ} \mathrm{C}$ for 1 hour. The liquid was again transferred to a fresh tube, and the liquid containing the peptides was finally vacuum dried and analyzed by MS. The detailed methods were performed as described in a previous study [62].

The identified differentially expressed proteins were functionally categorized by using the Gene Ontology Tool. The Go enrichment analysis was performed using GOEAST [63].

\section{Additional material}

Additional file 1: Outline of procedures used in CDNA library

analysis (pdf). Flowchart of the steps used for the cDNA library analysis.

Each step is shown on the left, and the corresponding number is listed on the right.

Additional file 2: The detailed information of the sequences from the cDNA library (xls).

Additional file 3: List of the predicted SRNA candidates in Xoo PXO99 ${ }^{A}$ using SIPHT search and the comparison of the results of the cloned sequences with the prediction results (x|s).

Additional file 4: 5' RACE results (xls).

Additional file 5: Predicted secondary structure of Xoo sRNAs (pdf). Secondary structures of eight Xoo sRNAs were predicted using MFOLD program.

Additional file 6: RT-PCR confirmation of the transcriptional unit of the $h f q$ gene (pdf). (A) The position and direction of ORFs were presented by arrows, and the corresponding names for each ORFs were also showed. The locations of primers used in the following PCR were presented by arrows. (B) RNAs prepared from wild-type cells cultured in rich (R) and minimum (M) medium were used for the reverse transcription using random primers to synthesis CDNA separately. DNA, positive control; +, with reverse transcriptase; -, without reverse transcriptase (a negative control to show no contamination of genomic DNA in the RNA sample).

Additional file 7: Growth characteristics of the $\Delta h f q$ mutant in rich medium (pdf). $\mathrm{OD}_{600}$ values of triplicate cultures in PSA medium were determined in two hour intervals (diamonds: wild-type; squares: $\triangle h f q$; triangles: $\triangle h f q-C, h f q$ complementary strain).

Additional file 8: 2-DE map of the total proteins from wild-type and the sRNA-deleted mutant strains (pdf). (A) 2-DE maps of total proteins from Xoo wild-type strain and $\triangle$ SRNA-Xoo3 mutant. (B) 2-DE maps of total proteins from $X_{0 O}$ wild-type strain and $\triangle$ SRNA-Xoo4 mutant. Protein spots indicated by numbers are the differentially expressed proteins. All these spots were identified by MS.
Additional file 9: Differentially expressed proteins in $\triangle$ sRNA-Xoo3 and $\triangle$ SRNA-Xoo4 identified by MS (pdf).

Additional file 10: The distribution of cis-encoded SRNA candidates and the functional classification of their putative target genes (xls). Additional file 11: Strains and plasmids used in this study (pdf). Additional file 12: Oligonucleotides used in this study (pdf).

\section{Acknowledgements}

We are grateful to Prof. Guixian Xia (Institute of Microbiology, CAS, China) for the help in the 2-DE experiment. We also thank Dr. Yuanming Luo (Institute of Microbiology, CAS, China) for technical assistance with MS analysis. This work was supported by grants from the Ministry of Science and Technology of China (2006AA02Z122) and the Major State Basic Research Development Program of China (973 program 2011CB100700).

\section{Author details}

'State Key Laboratory of Plant Genomics, Institute of Microbiology, Chinese Academy of Sciences, Beijing 100101, PR China. ${ }^{2}$ National Center for Plant Gene Research, Beijing 100101, PR China. ${ }^{3}$ Graduate School of the Chinese Academy of Sciences, Beijing 100039, PR China. ${ }^{4}$ State Key Laboratory of Plant Genomics, Institute of Genetics and Developmental Biology, Chinese Academy of Sciences, Beijing 100101, PR China.

\section{Authors' contributions}

$\mathrm{HL}$ carried out the experiments, analyzed the primary data and wrote the draft manuscript; YTZ performed the bioinformatic related analysis; JQZ participated in clone construction and 2-DE, XJW, RXF and YTJ assisted with experimental design, data analysis, supervised the whole work and revised the manuscript. All authors have read, approved and made contributions to the final manuscript.

Received: 26 October 2010 Accepted: 30 January 2011

Published: 30 January 2011

\section{References}

1. Wassarman KM: Small RNAs in bacteria: diverse regulators of gene expression in response to environmental changes. Cell 2002, 109(2):141-144.

2. Bejerano-Sagie M, Xavier KB: The role of small RNAs in quorum sensing. Curr Opin Microbiol 2007, 10(2):189-198.

3. Grieshaber NA, Grieshaber SS, Fischer ER, Hackstadt T: A small RNA inhibits translation of the histone-like protein $\mathrm{Hc} 1$ in Chlamydia trachomatis. Mol Microbiol 2006, 59(2):541-550.

4. Lenz DH, Miller MB, Zhu J, Kulkarni RV, Bassler BL: CsrA and three redundant small RNAs regulate quorum sensing in Vibrio cholerae. Mol Microbiol 2005, 58(4):1186-1202.

5. Ma W, Cui Y, Liu Y, Dumenyo CK, Mukherjee A, Chatterjee AK: Molecular characterization of global regulatory RNA species that control pathogenicity factors in Erwinia amylovora and Erwinia herbicola pv. gypsophilae. J Bacteriol 2001, 183(6):1870-1880.

6. Burrowes E, Abbas A, O'Neill A, Adams C, O'Gara F: Characterisation of the regulatory RNA RsmB from Pseudomonas aeruginosa PAO1. Res Microbiol 2005, 156(1):7-16.

7. Papenfort K, Vogel J: Regulatory RNA in bacterial pathogens. Cell Host Microbe 2010, 8(1):116-127.

8. Wassarman KM, Repoila F, Rosenow C, Storz G, Gottesman S: Identification of novel small RNAs using comparative genomics and microarrays. Genes Dev 2001, 15(13):1637-1651.

9. Rivas E, Klein RJ, Jones TA, Eddy SR: Computational identification of noncoding RNAs in E. coli by comparative genomics. Curr Biol 2001, 11(17):1369-1373.

10. Vogel J, Bartels V, Tang TH, Churakov G, Slagter-Jager JG, Huttenhofer A, Wagner EG: RNomics in Escherichia coli detects new sRNA species and indicates parallel transcriptional output in bacteria. Nucleic Acids Res 2003, 31(22):6435-6443.

11. Kawano M, Reynolds AA, Miranda-Rios J, Storz G: Detection of 5'- and 3'UTR-derived small RNAs and cis-encoded antisense RNAs in Escherichia coli. Nucleic Acids Res 2005, 33(3):1040-1050. 
12. Vogel J: A rough guide to the non-coding RNA world of Salmonella. Mol Microbiol 2009, 71(1):1-11.

13. Livny J, Brencic A, Lory S, Waldor MK: Identification of 17 Pseudomonas aeruginosa sRNAs and prediction of sRNA-encoding genes in 10 diverse pathogens using the bioinformatic tool sRNA Predict2. Nucleic Acids Res 2006, 34(12):3484-3493.

14. Pichon C, Felden B: Small RNA genes expressed from Staphylococcus aureus genomic and pathogenicity islands with specific expression among pathogenic strains. Proc Natl Acad Sci USA 2005, 102(40):14249-14254

15. del Val C, Rivas E, Torres-Quesada O, Toro N, Jimenez-Zurdo Jl: Identification of differentially expressed small non-coding RNAs in the legume endosymbiont Sinorhizobium meliloti by comparative genomics. Mol Microbiol 2007, 66(5):1080-1091.

16. Mandin P, Repoila F, Vergassola M, Geissmann T, Cossart P: Identification of new noncoding RNAs in Listeria monocytogenes and prediction of mRNA targets. Nucleic Acids Res 2007, 35(3):962-974.

17. Landt SG, Abeliuk E, McGrath PT, Lesley JA, McAdams HH, Shapiro L: Small non-coding RNAs in Caulobacter crescentus. Mol Microbiol 2008, 68(3):600-614.

18. Arnvig KB, Young DB: Identification of small RNAs in Mycobacterium tuberculosis. Mol Microbiol 2009, 73(3):397-408.

19. Gottesman S, Storz G: Bacterial Small RNA Regulators: Versatile Roles and Rapidly Evolving Variations. Cold Spring Harb Perspect Biol 2010.

20. Waters LS, Storz G: Regulatory RNAs in bacteria. Cell 2009, 136(4):615-628.

21. Valentin-Hansen $P$, Eriksen $M$, Udesen C: The bacterial Sm-like protein Hfq: a key player in RNA transactions. Mol Microbiol 2004, 51(6):1525-1533.

22. Aiba H: Mechanism of RNA silencing by Hfq-binding small RNAs. Curr Opin Microbiol 2007, 10(2):134-139.

23. Christiansen JK, Larsen $M H$, Ingmer $H$, Sogaard-Andersen $L$, Kallipolitis BH: The RNA-binding protein Hfq of Listeria monocytogenes: role in stress tolerance and virulence. J Bacteriol 2004, 186(11):3355-3362.

24. Tsui HC, Leung HC, Winkler ME: Characterization of broadly pleiotropic phenotypes caused by an $h f q$ insertion mutation in Escherichia coli K-12. Mol Microbiol 1994, 13(1):35-49.

25. Robertson GT, Roop RM Jr: The Brucella abortus host factor I (HF-I) protein contributes to stress resistance during stationary phase and is a major determinant of virulence in mice. Mol Microbiol 1999, 34(4):690-700.

26. Ding Y, Davis BM, Waldor MK: Hfq is essential for Vibrio cholerae virulence and downregulates sigma expression. Mol Microbiol 2004, 53(1):345-354.

27. Sonnleitner E, Hagens S, Rosenau F, Wilhelm S, Habel A, Jager KE, Blasi U: Reduced virulence of a hfg mutant of Pseudomonas aeruginosa 01. Microb Pathog 2003, 35(5):217-228.

28. Sittka A, Pfeiffer V, Tedin K, Vogel J: The RNA chaperone Hfq is essential for the virulence of Salmonella typhimurium. Mol Microbiol 2007, 63(1):193-217.

29. Brantl S: Bacterial chromosome-encoded small regulatory RNAs. Future Microbiol 2009, 4(1):85-103.

30. Brantl S: Regulatory mechanisms employed by cis-encoded antisense RNAs. Curr Opin Microbiol 2007, 10(2):102-109.

31. Lee BM, Park YJ, Park DS, Kang HW, Kim JG, Song ES, Park IC, Yoon UH, Hahn JH, Koo BS, Lee GB, Kim H, Park HS, Yoon KO, Kim JH, Jung CH, Koh NH, Seo JS, Go SJ: The genome sequence of Xanthomonas oryzae pathovar oryzae KACC10331, the bacterial blight pathogen of rice. Nucleic Acids Res 2005, 33(2):577-586.

32. Hirokazu OCHIAI YI, Masaru TAKEYA, Aeni SASAKI and, KAKU H: Genome sequence of Xanthomonas oryzae pv. oryzae suggests contribution of large numbers of effector genes and insertion sequences to its race diversity. JARQ 2005, 39(4):275-287.

33. Salzberg SL, Sommer DD, Schatz MC, Phillippy AM, Rabinowicz PD, Tsuge S, Furutani A, Ochiai H, Delcher AL, Kelley D, Madupu R, Puiu D, Radune D, Shumway M, Trapnell C, Aparna G, Jha G, Pandey A, Patil PB, Ishihara H, Meyer DF, Szurek B, Verdier V, Koebnik R, Dow JM, Ryan RP, Hirata H, Tsuyumu S, Won Lee S, Seo YS, et al: Genome sequence and rapid evolution of the rice pathogen Xanthomonas oryzae pv. oryzae PXO99A. BMC Genomics 2008, 9:204.

34. Griffiths-Jones S, Moxon S, Marshall M, Khanna A, Eddy SR, Bateman A: Rfam: annotating non-coding RNAs in complete genomes. Nucleic Acids Res 2005, 33 Database: D121-124.
35. Semenova E, Nagornykh M, Pyatnitskiy M, Severinov K: Analysis of CRISPR system function in plant pathogen Xanthomonas oryzae. FEMS Microbiol Lett 2009, 296(1):110-116

36. Jiang RP, Tang DJ, Chen XL, He YQ, Feng JX, Jiang BL, Lu GT, Lin M, Tang JL: Identification of four novel small non-coding RNAs from Xanthomonas campestris pathovar campestris. BMC Genomics 2010, 11(1):316.

37. Findeiss $S$, Schubert $C$, Stadler PF, Bonas U: A novel family of plasmidtransferred anti-sense ncRNAs. RNA Biol 2010, 7(2):120-124.

38. Argaman L, Hershberg R, Vogel J, Bejerano G, Wagner EG, Margalit $H$, Altuvia S: Novel small RNA-encoding genes in the intergenic regions of Escherichia coli. Curr Biol 2001, 11(12):941-950.

39. Delcher AL, Harmon D, Kasif S, White O, Salzberg SL: Improved microbial gene identification with GLIMMER. Nucleic Acids Res 1999, 27(23):4636-4641.

40. Shultzaberger RK, Bucheimer RE, Rudd KE, Schneider TD: Anatomy of Escherichia coli ribosome binding sites. J Mol Biol 2001, 313(1):215-228.

41. Livny J, Teonadi H, Livny M, Waldor MK: High-throughput, kingdom-wide prediction and annotation of bacterial non-coding RNAs. PLOS One 2008, 3(9):e3197.

42. Sonnleitner E, Sorger-Domenigg T, Madej MJ, Findeiss S, Hackermuller J, Huttenhofer A, Stadler PF, Blasi U, Moll I: Detection of small RNAs in Pseudomonas aeruginosa by RNomics and structure-based bioinformatic tools. Microbiology 2008, 154(10):3175-3187.

43. Swiercz JP, Bobek J, Bobek J, Haiser HJ, Di Berardo C, Tjaden B, Elliot MA: Small non-coding RNAs in Streptomyces coelicolor. Nucleic Acids Res 2008, 36(22):7240-7251.

44. Chao Y, Vogel J: The role of Hfq in bacterial pathogens. Curr Opin Microbiol 2010, 13(1):24-33.

45. Sharma CM, Hoffmann S, Darfeuille F, Reignier J, Findeiss S, Sittka A, Chabas S, Reiche K, Hackermuller J, Reinhardt R, Stadler PF, Vogel J: The primary transcriptome of the major human pathogen Helicobacter pylori. Nature 2010, 464(7286):250-255.

46. Ferguson $A D$, Deisenhofer J: Metal import through microbial membranes. Cell 2004, 116(1):15-24.

47. Noinaj N, Guillier M, Barnard TJ, Buchanan SK: TonB-Dependent Transporters: Regulation, Structure, and Function. Annu Rev Microbiol 2010, 64:43-60.

48. Qian W, Jia Y, Ren SX, He YQ, Feng JX, Lu LF, Sun Q, Ying G, Tang DJ, Tang $H$, Wu W, Hao P, Wang L, Jiang BL, Zeng $S$, Gu WY, Lu G, Rong L, Tian Y, Yao Z, Fu G, Chen B, Fang R, Qiang B, Chen Z, Zhao GP, Tang JL, $\mathrm{He} C$ : Comparative and functional genomic analyses of the pathogenicity of phytopathogen Xanthomonas campestris pv. campestris. Genome Res 2005, 15(6):757-767.

49. Blanvillain S, Meyer D, Boulanger A, Lautier M, Guynet C, Denance N, Vasse J, Lauber E, Arlat M: Plant carbohydrate scavenging through TonBdependent receptors: a feature shared by phytopathogenic and aquatic bacteria. PLoS One 2007, 2(2):e224.

50. Subramoni S, Sonti RV: Growth deficiency of a Xanthomonas oryzae pv. oryzae fur mutant in rice leaves is rescued by ascorbic acid supplementation. Mol Plant Microbe Interact 2005, 18(7):644-651.

51. Masse $E$, Gottesman S: A small RNA regulates the expression of genes involved in iron metabolism in Escherichia coli. Proc Natl Acad Sci USA 2002, 99(7):4620-4625.

52. Jacques JF, Jang S, Prevost K, Desnoyers G, Desmarais M, Imlay J, Masse E: RyhB small RNA modulates the free intracellular iron pool and is essential for normal growth during iron limitation in Escherichia coli. Mol Microbiol 2006, 62(4):1181-1190.

53. Salvail H, Lanthier-Bourbonnais P, Sobota JM, Caza M, Benjamin JA, Mendieta ME, Lepine F, Dozois CM, Imlay J, Masse E: A small RNA promotes siderophore production through transcriptional and metabolic remodeling. Proc Natl Acad Sci USA 2010, 107(34):15223-15228.

54. Prevost K, Salvail H, Desnoyers G, Jacques JF, Phaneuf E, Masse E: The small RNA RyhB activates the translation of shiA mRNA encoding a permease of shikimate, a compound involved in siderophore synthesis. Mol Microbiol 2007, 64(5):1260-1273.

55. Huttenhofer A, Vogel J: Experimental approaches to identify non-coding RNAs. Nucleic Acids Res 2006, 34(2):635-646.

56. Yuan G, Klambt C, Bachellerie JP, Brosius J, Huttenhofer A: RNomics in Drosophila melanogaster: identification of 66 candidates for novel nonmessenger RNAs. Nucleic Acids Res 2003, 31(10):2495-2507. 
57. Joseph Sambrook DR: Molecular Cloning: A Laboratory Manual. Third edition. Cold Spring Harbor Laboratory Press, Cold Spring Harbor, NY; Spring Harbor; 2001.

58. Hartmann RKBA, Schön A, Westhof E, Wiley-VCH : Handbook of RNA Biochemistry 2005, 2:614-642.

59. Schafer A, Tauch A, Jager W, Kalinowski J, Thierbach G, Puhler A: Small mobilizable multi-purpose cloning vectors derived from the Escherichia coli plasmids pK18 and pK19: selection of defined deletions in the chromosome of Corynebacterium glutamicum. Gene 1994, 145(1):69-73.

60. Dow JM, Clarke BR, Milligan DE, Tang JL, Daniels MJ: Extracellular proteases from Xanthomonas campestris pv. campestris, the black rot pathogen. Appl Environ Microbiol 1990, 56(10):2994-2998.

61. Tang JL, Liu YN, Barber CE, Dow JM, Wootton JC, Daniels MJ: Genetic and molecular analysis of a cluster of rpf genes involved in positive regulation of synthesis of extracellular enzymes and polysaccharide in Xanthomonas campestris pathovar campestris. Mol Gen Genet 1991, 226(3):409-417.

62. Zhao PM, Wang LL, Han LB, Wang J, Yao Y, Wang HY, Du XM, Luo YM, Xia GX: Proteomic identification of differentially expressed proteins in the Ligon lintless mutant of upland cotton (Gossypium hirsutum L.). J Proteome Res 2010, 9(2):1076-1087.

63. Zheng $\mathrm{Q}$, Wang XJ: GOEAST: a web-based software toolkit for Gene Ontology enrichment analysis. Nucleic Acids Res 2008, 36 Web Server: W358-363.

\section{doi:10.1186/1471-2164-12-87}

Cite this article as: Liang et al: Identification and functional characterization of small non-coding RNAs in Xanthomonas oryzae pathovar oryzae. BMC Genomics 2011 12:87.

\section{Submit your next manuscript to BioMed Central and take full advantage of:}

- Convenient online submission

- Thorough peer review

- No space constraints or color figure charges

- Immediate publication on acceptance

- Inclusion in PubMed, CAS, Scopus and Google Scholar

- Research which is freely available for redistribution

Submit your manuscript at www.biomedcentral.com/submit 